\title{
Assessment of Anti-HBs Antigen in 6- to 9-Year-Old Children Routinely Vaccinated via Vaccination Program in Iran
}

\author{
Nahal Hadi ${ }^{a}$ Negin Hadi ${ }^{b}$ \\ ${ }^{a}$ Department of Bacteriology and Virology, and ${ }^{b}$ Department of Community Medicine, Medical School, \\ Shiraz University of Medical Science, Shiraz, Iran
}

\section{Key Words}

Hepatitis • Vaccination · Anti-HBV antigen · Children · Iran

\begin{abstract}
Objective: To determine persisting antibody levels to hepatitis $B$ virus (HBV) antigen in healthy children, aged 6-9 years, vaccinated at birth. Methods: Blood samples were collected from 374 vaccinated children (178 girls and 196 boys) and 57 unvaccinated children, attending Shiraz Primary School, Shiraz, Iran from September 2002 to April 2003. An HBV surface antibody (anti-HBs) was determined using enzyme-linked immunosorbent assay. Results: The anti-HBs titer was detected in $17 \%$ of the 8 -year-old children, $7.7 \%$ of the 7 -yearold children and $46.6 \%$ of the 6 -year-old children. The decrease was greatest in the 9-year-old children; more than half (54.3\%) had a titer of less than $10 \mathrm{lU} / \mathrm{ml}$, indicating a decrease in antibody levels with increasing age/time. Conversely, more than $35 \%$ of the 6 -year-old children had a titer greater than $150 \mathrm{IU} / \mathrm{ml}$ compared with 24,12 and $7 \%$ of children at the age of 7, 8 and 9, respectively, whose antibody titer was less than $150 \mathrm{lU} / \mathrm{ml}$. Conclusion: Antibody titer declined with time. In comparison with other countries, the antibody titer in Iranian children was much lower.
\end{abstract}

Copyright $\odot 2007$ S. Karger AG, Basel
(C) 2007 S. Karger AG, Basel

$1011-7571 / 07 / 0164-0306 \$ 23.50 / 0$

Fax +4161306 1234

E-Mail karger@karger.ch

www.karger.com
Accessible online at: www.karger.com/mpp

\section{Introduction}

More than 300 million people worldwide are persistently infected with hepatitis B virus (HBV) and a significant proportion of these people develop severe pathologic consequences such as chronic hepatitis, cirrhosis and hepatocellular carcinoma [1]. In Iran, hepatitis B carrier rate was reported to be $1.7 \%$ in 1996 [2]. Among Iranian patients with cirrhosis, $70-84 \%$ had evidence of exposure to HBV and $51-56 \%$ are carriers. Patients with hepatocellular carcinoma show a $72 \%$ rate of exposure [3].

Immunization with hepatitis $\mathrm{B}$ vaccine is considered an effective means of prevention of infection with $\mathrm{HBV}$ and reducing occurrence of chronic sequelae related to the illness [4]. However, the disease still remains a global problem. Many factors contribute to the failure to control hepatitis B infection and morbidity, including the limiting nature of vaccination programs implemented initially. Universal childhood HBV immunization may have a significant impact in decreasing the number of people with chronic HBV infection and this may limit its spread. The most common method employed for the prevention of HBV infection in the Middle East is by active immunization [5]. In Iran, since $1984 \mathrm{HBV}$ vaccination of children at birth and high-risk groups was implemented by the Expanded Program of Immunization (EPI) [6]. 
Table 1. Distribution of antibody against $\mathrm{HBs}$ antigen $(\mathrm{mIU} / \mathrm{ml})$ by age and gender

\begin{tabular}{|c|c|c|c|c|c|c|c|c|c|c|c|c|}
\hline Age & $\mathrm{n}(\%)$ & $\begin{array}{l}\text { mean } \\
\text { (median) }\end{array}$ & SD & SE & n (\%) & $\begin{array}{l}\text { mean } \\
\text { (median) }\end{array}$ & $\mathrm{SD}$ & SE & n (\%) & $\begin{array}{l}\text { mean } \\
\text { (median) }\end{array}$ & $\mathrm{SD}$ & SE \\
\hline 6 years & $14(7.1)$ & 127 (118) & 105.5 & 8.2 & $37(20.8)$ & $92.5(55.4)$ & 82.7 & 13.6 & $51(13.6)$ & $101.9(70)$ & 89.8 & 12.6 \\
\hline 7 years & $51(26)$ & $97.2(84.2)$ & 85.5 & 11.9 & $55(30.9)$ & $73.2(43)$ & 75.3 & 10.1 & $106(28.4)$ & $84.8(63.8)$ & 80.9 & 7.8 \\
\hline 8 years & $67(34.2)$ & $52.4(12.5)$ & 68.6 & 8.4 & $58(32.6)$ & $52.6(19.4)$ & 68.8 & 9.0 & $125(33.4)$ & $52.5(15.4)$ & 68.5 & 6.1 \\
\hline Total & $196(100)$ & $64.8(22.8)$ & 78.9 & 5.6 & $178(100)$ & $61.9(25.9)$ & 72.9 & 5.5 & $374(100)$ & $63.4(23.7)$ & 76 & 3.9 \\
\hline
\end{tabular}

$\mathrm{p}<0.001$

$\mathrm{HBV}$ vaccine is shown to be immunogenic and effective in preventing infection [7]. For ensuring that sustained immunity is conferred, antibody titer could be monitored. However, in Shiraz, it is not a general policy to monitor the long-term persistence of antibodies induced by vaccination.

The age at which HBV is acquired is an important factor in the development of chronic HBV infection. Followup studies of children vaccinated at birth have shown that a continued high level of protection against chronic infection persists for at least 5 years [8-10]. However, the exact duration of protection which the vaccine confers is unclear. The Center for Disease Control and Prevention continues to study children immunized at birth to determine whether or not boosters are required later in life. Also, in the interest of containing this infection, many studies have been conducted in different countries in order to assess the effect and duration of the recombinant vaccine [14-16]. Similarly, it is necessary to know the level of antibody response sustained in Iranian children included in the International Vaccine Program to receive recombinant vaccine and monitor antibody levels.

In this study, the duration of persisting anti-HBs antigen was determined among 6- to 9-year-old schoolchildren vaccinated at birth and who received two booster doses of HBV vaccine via a routine vaccination program.

\section{Subjects and Methods}

Blood samples were obtained from 374 (178 girls and 196 boys) healthy primary schoolchildren aged 6-9 years, living in Shiraz, southern Iran, from September 2002 to April 2003. Using the cluster random sampling method, questionnaires were given to the parents of the children, to provide the medical history of their children. Written informed consent was obtained from all of the parents. As recorded on their vaccination cards, the children were vaccinated with HBV: each with a total of three doses: one at birth and two booster doses at 2 and 6 months. Unvaccinated children (57children, 25 boys and 32 girls) were selected as controls.

The sera from the blood samples were preserved at $-20^{\circ} \mathrm{C}$. Enzyme-linked immunosorbent assay kits (Equipar, Italy) were used for detecting $\mathrm{HBs}$ antibody in the sera. One of the two purified HBs antigens was bound to the microplate and the second one was conjugated with the peroxidase (horseradish peroxidase). The antigen and antibody formed a sandwich complex with the antibodies, when present in the sample. The enzymatic activity was detected by incubation with the specific chromogen/substrate $3,3^{\prime}, 5,5^{\prime}$-tetramethylbenzidine (TMB). The color intensity of TMB was proportional to the amount of antibody in the specimens. The TMB levels were quantified using the reference standard (WHO) [11]. Microplates were read at $450 \mathrm{~nm}$ and a subtract fitting system was used and the concentrations of the HBsAb in the samples were determined on the standard curve.

Data were analyzed using chi-square, one-way ANOVA and cross-tabulation for assessing any difference in antibody titer levels between and within groups, using SPSS 12.5, probability value of $\mathrm{p}<0.05$.

\section{Results}

$\mathrm{HBsAb}$ concentrations higher than $10 \mathrm{IU} / \mathrm{ml}$ were considered to be sufficiently high to afford immunity against HBV infection. The specificity and sensitivity of the assay were $>99$ and $98 \%$, respectively.

Measurement of antibody titer against $\mathrm{HBs}$ antigen showed a decrease in mean antibody titer at 7,8 , and 9 years of age (table 1 ).

About one third of all vaccinated children at birth (35.2\%, $\mathrm{n}=69$ girls, and $33.7 \%, \mathrm{n}=59$ boys) had antibody titers less than $10 \mathrm{IU} / \mathrm{ml}$. A quarter of them $(25 \%$ of girls, $\mathrm{n}=49$, and $27.5 \%$ of boys, $\mathrm{n}=49$, respectively) had titers 
Fig. 1. Distribution of antibody titer (IU/ $\mathrm{ml}$ ) against antigen in various age groups.

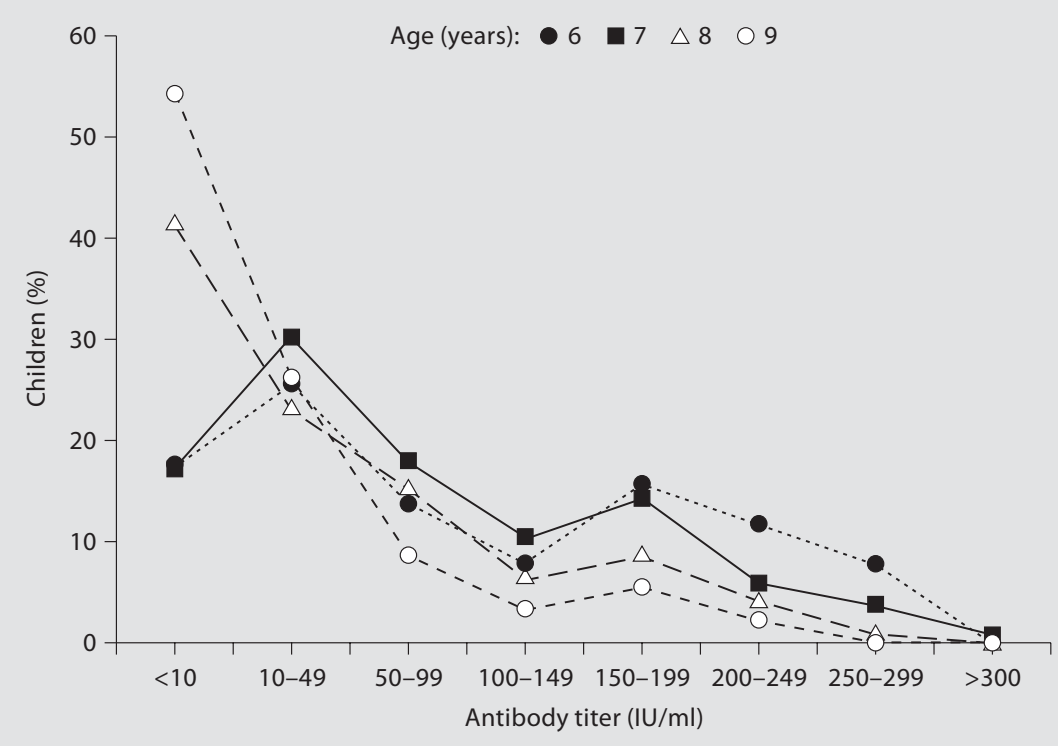

of $10-50 \mathrm{IU} / \mathrm{ml}$. High titer levels, $50-100 \mathrm{IU} / \mathrm{ml}$, were noted in considerably fewer individuals: $12.45 \%$ girls and $14.9 \%$ boys ( $\mathrm{n}=24$ and $\mathrm{n}=26$, respectively); $100-150 \mathrm{IU} /$ $\mathrm{ml}$ in $8.16 \%$ girls and $5.61 \%$ boys, and $150-200 \mathrm{IU} / \mathrm{ml}$ in $9.8 \%$ girls $(\mathrm{n}=19)$ and $11.79 \%$ boys $(\mathrm{n}=20)$. A small number of children $(2.67 \%, \mathrm{n}=10)$ had a titer greater than 200 $\mathrm{IU} / \mathrm{ml}$. Antibody titer was not detected in the unvaccinated group.

A substantial decrease in antibody titer was noted at 9 years, so that $54.3 \%(n=50)$ had titers less than $10 \mathrm{IU} / \mathrm{ml}$. Only a small percentage $(19.6 \%, \mathrm{n}=18)$ had a titer above $50 \mathrm{IU} / \mathrm{ml}$.

Children who were 8 years of age (39.7\% of the boys, $\mathrm{n}=23$, and $43.3 \%$ of the girls, $\mathrm{n}=29$ ) had a titer of less than $10 \mathrm{IU} / \mathrm{ml}$, but $23 \%$ of this group had $10-50 \mathrm{IU} / \mathrm{ml}$. Compared to the titers of 50-99 IU/ml of 9 -year-old children, there were a greater number of children with antibody titers of $50-99 \mathrm{IU} / \mathrm{ml}(15.2 \%, \mathrm{n}=19)$.

Of the 106 individuals who were 7 years old, $17 \%$ ( $=$ 18) had titers less than $10 \mathrm{IU} / \mathrm{ml}$. More than $30 \%$ of these children $(\mathrm{n}=32)$ had titers between 10 and $49 \mathrm{IU} / \mathrm{ml}$, whereas $17.9 \%(\mathrm{n}=19), 10.4 \%(\mathrm{n}=11)$ and $14.3 \%(\mathrm{n}=15)$ had titers in the range of 50-99, 100-140, and 150-199 $\mathrm{IU} / \mathrm{ml}$, respectively. A small percentage $(10.4 \%, \mathrm{n}=11)$ had titers > $200 \mathrm{IU} / \mathrm{ml}$. In the 6-year-old group, out of 51 children 9 had less than $10 \mathrm{IU} / \mathrm{ml}$ (a total of 17.7\%). A greater number of children $(25 \%, \mathrm{n}=13)$ had titers between 10 and $40 \mathrm{IU} / \mathrm{ml}$ and the rest $(60 \%, \mathrm{n}=30)$ had titers greater than $50 \mathrm{IU} / \mathrm{ml}$ (fig. 1).
The difference in titer levels between genders was not statistically significant but the differences between and within age groups were statistically significant $(\mathrm{p}<0.001)$, showing that circulating levels of antibody titers decreased with time.

\section{Discussion}

Several studies are being conducted to assess the duration of immune response in individuals initially vaccinated during infancy with a recombinant vaccine [1517]. This is to determine if immunity lasts to confer protection into adulthood.

Our results showed that the duration of vaccine efficacy in Iranian children was lower compared to that reported in other countries. About $50 \%$ of 9 -year-old children had an antibody titer less than $10 \mathrm{IU} / \mathrm{ml}$.

Overall, the antibody titer was considerably low, but the trend in reduction of antibody titer is similar to the study on neonates in New Zealand who were vaccinated at birth; the vaccine proved to be highly immunogenic. In that study of 704 children who were given HBV vaccine at birth, it was shown that $96.7 \%$ of 1 - to 4 -year-old children had detectable anti-HBs, compared to $91 \%$ of 5 to 9 -year-old children and $81 \%$ of 10 - to 14 -year-old children [12]. In another study, $66 \%$ of children aged 5-9 years had antibody titers above $50 \mathrm{IU} / \mathrm{ml}$ [13]. 
Since only a few (17\%) 6-year-old children had very low antibody titers $(<10 \mathrm{IU} / \mathrm{ml})$, it can be concluded that vaccination performed at birth had a good response and immunogenicity persists in most individuals. The reason as to why $17 \%$ of children did not have a good response needs further investigation.

It is interesting to note and investigate why immunity declines very much more rapidly among children in this study in Shiraz, as compared to other countries. Also, the question arises, since immunity diminishes significantly by $9-10$ years following vaccination, whether there should be a policy of giving a booster dose to children older than 10 years.

\section{Conclusion}

Among Iranian children vaccinated at birth, immunogenicity, i.e. antibody titer to $\mathrm{HBV}$, diminished at a higher rate than reported elsewhere.

\section{Acknowledgments}

The authors would like to thank Dr. Mohammadreza Aram and Dr. Raja Majed-Khan for taking blood samples, Dr. Farhad Handjani for his editorial assistance and the Deputy of Research of Shiraz University, Medical Science, for financial support.

\section{References}

1 Knipe DM, Howley PM (eds): Fundamental Virology, ed 4. Philadelphia, Lippincot, Williams \& Wilkins, 2001, pp 1285-1318.

2 Zali MR, Mohammad K, Farhadi A, Masjedi MR, Zargar A, Noroozi A: Epidemiology of hepatitis B in the Islamic Republic of Iran. East Mediterr Health J 1996;2:290-298.

3 Shamszad M, Farzadgan H: Hepatitis B related cirrhosis and hepatocellular carcinoma in Iran. J Iran Med Council 1982;8:238.

-4 Jilg W, Lorbee B, Schmidt M, Wilske B, Zoulek G, Deinhard T: Clinical evaluation of a recombinant hepatitis B vaccine. Lancet 1984;ii:1174-1175.

5 Qirbi N, Hall AJ: Epidemiology of hepatitis $\mathrm{B}$ in the Middle East. East Mediterr Health J 2001;6:1034-1045.

6 Nedelcu I, Gacium D, Tardei G, Ruta SM: Assessment of the anti-hepatitis $B$ vaccination efficacy in high risk children. Rom J Virol 1998;49:4351.

7 Galimska J: Epidemiological section, Ministry of Health and Social Welfare. The Expanded Program on Immunization Calendar in Poland. Vaccine 2000;18(suppl 18): 1541-1543.
8 Dienstag JL, Isselbacher KJ: Acute viral hepatitis; in Braunwald E, Wonsiewicz M, Englis MR (eds): Harrison's Principles of Internal Medicine, ed 15. New York, McGraw-Hill, 2001, vol 2, pp 1723-1724.

-9 Hyams K: Risks of chronicity following acute hepatitis B virus infection: a review. Clin Infect Dis 1995;20:992-1000.

10 Advances in Viral Hepatitis. Report of the WHO Expert Committee on Viral Hepatitis. World Health Organ Tech Rep Ser 1977; No 602.

11 Hepatitis B surface antigen assays: operational characteristics (phase 1). Report 2. Geneva, World Health Organization, 2004. www.who.int/ehtl.

12 Milne A, Mimitrakakis M, Allwood G, Lucas R, Moyes C, Pearce N: Immunogenicity of low doses of hepatitis $B$ vaccine in children: a study in $650 \mathrm{New}$ Zealand children. J Med Virol 1987;23:401-405.
13 Tsebe KV, Burnett RJ, Hlungwani NP, Sibara MM, Venter PA, Mphahlele MJ: The first five years of universal hepatitis $B$ vaccination in South Africa: evidence for elimination of HBsAg carriage in under 5-year-olds. Vaccine 2001;19:3919-3926.

14 Bonanni P, Colombai R, Gasparini R, Lo Nostro A, Tiscione E, Tomei A, Montomoli E, Comodo N: Impact of routine infant and adolescent hepatitis B vaccination in Tuscany, Central Italy. Pediatr Infect Dis J 1999;18: 677-682.

15 Progress in the control of viral hepatitis: memorandum from a WHO meeting. Bull World Health Organ 1988;66:443-455.

16 Xu ZY, Liu CB, Francis DP, Purcell RH, Gun ZL, Duan SC, Chen RJ, Margolis HS, Huang $\mathrm{CH}$, Maynard JE: Prevention of perinatal acquisition of hepatitis B virus carriage using vaccine: preliminary report of a randomized, double-blind placebo-controlled and comparative trial. Pediatrics 1985;76:713-718.

- 17 Stevens CE, Alter HJ, Taylor PE, Zang EA, Harley EJ, Szmuness W: Hepatitis B vaccine in patients receiving hemodialysis: immunogenicity and efficacy. N Engl J Med 1984; 311:496-501. 